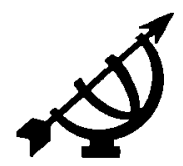

\title{
Career role modelling: a challenge to career education
}

\author{
S. Landsberg \& J.L. Marais \\ Graduate School of Education \\ Potchefstroom University for CHE \\ POTCHEFSTROOM \\ E-mail: dopjlm@puknet.puk.ac.za
}

\section{Abstract \\ Career role modelling: a challenge to career education}

The aim of this article is to determine to what extent a career role modelling programme as method of career information dissemination for all communities, but especially of service to the disadvantaged, can be instrumental in addressing the existing void in the career information dissemination system in South Africa.

It was determined that a career role modelling programme can make a significant contribution to establishing an inexpensive and effective career information system in a diverse South African society.

\section{Introduction}

In South Africa most pupils, especially in disadvantaged communities, do not receive sufficient career information. A lack of a co-ordinated and affordable system on career information is experienced on ground level (Landsberg, 1996:11). There are, however, several methods of career information dissemination. Career role modelling, for instance, is an inexpensive and affordable method that can be implemented by all guidance teachers and schools, but can be an outcome for schools, even those in disadvantaged communities. According to Isaacson (1986:433) the term disadvantaged can be interpreted very broadly. In its usual "dictionary" sense disadvantaged includes everyone in an unfavourable economic or social situation.

Realistic and practical information about the occupational milieu can be used to help the disadvantaged to see potential opportunities to break out of a "hopeless morass". Interviews with workers, work samples, plant visits and simulated work situations may help a person to understand the job, and to relate to it in order to 
1991:48, 58). This kind of response is nomally conditioned by world-view, and in the case of the Christian for example, it would be accepted that Christ fulfils this ideal role.

\subsection{Model}

Webster's third new international dictionary (Gove, 1961:1451) defines a "model" as:

- a person or thing regarded as worthy of imitation: something perfect of its kind;

- a person to be imitated; and

- that which embodies criteria for excellence and sets a high example for emulation.

Through imitation and modelling people observe the behaviour of others and accordingly develop behavioural patterns (Berger et al., 1991:41; Childs, 1993: 108-109).

A role model demonstrates to the "actor" how something is done. According to Jung (1986:525-526) the role model concept is derived from the concepts of role (based on role theory) and modelling (based on social learning theory). Blending the concepts of role and modelling is a way to explain how an "actor" is socialized into new roles. According to Farmer (as quoted by Borgotta \& Borgotta, 1992: 1678-1679) an observer adopts a particular role through exposure to a model.

According to the Oxford English Dictionary (1978:568-569) the word "model" can have the following denotations:

- a person or a work that is proposed or adopted for imitation; an exemplar;

- a person or thing eminently worthy of imitation: a perfect exemplar of some excellence.

The Christian believer should hold Jesus as the ideal model to follow because His example is worth following.

\section{Career role models}

In the light of the analyses of the above concepts a "career role model" can be described as an exemplary person

- representing a career that can be seen as an orderly change of positions up or down an occupational ladder over time. This progression is associated with changes in the individual's work tasks, autonomy, income, relations with coworkers and sense of self; 
- representing a role consisting of a set of behavioural patterns expected of people occupying a certain position in a social system; and

- who is a model regarded as worthy of imitation.

Gnaedinger (1996:2) defines a career role model as any person having contact with pupils or students and consequently illustrating his/her own career interests, what he/she does in his/her career, as well as the role of other people in the company. The Christian believer should find life fulfilment and joy in being of service to his/her fellow human beings through his/her example as a career devotee, the focus being on serving human needs.

According to Gnaedinger (1996:2) teachers themselves should be role models with regard to careers in education, and parents should be role models with regard to careers they pursue for a living. However, since teachers and parents are structural authority figures, someone else not part of that system would seem to be better choices as role models

Gnaedinger (1996:3) stresses that the most important thing about career role models is that they believe in a constructive, win-win life, and that they love children and hope that pupils will pursue careers that will keep them productive and happy at the same time.

\subsection{Social or live models}

According to Krumboltz and Thoresen (1969:163) imitation plays a crucial role in acquiring and regulating all kinds of social behaviour. The influence of social models consistently points out that "actions speak louder than words", that individuals, often inadvertently, do teach by example, e.g. parents. Social modelling is sometimes called imitative, vicarious or observational learning.

The live model is probably the most familiar prototype. Christ can be regarded the prototype against whom all other role models can be measured. A counsellor should deliberately try to be a live social model to demonstrate certain behavioural patterns to clients. Peers of the client may be employed as models in small group settings. Live models do present one problem for the counsellor in that he has less control over the behaviour of the model than he does with symbolic models. The live model may not demonstrate the relevant behaviour to the desired extent. The live model is also influenced by the observers and their responsiveness to him. Another problem is that a live modelling experience can be overwhelming for the client. The client as an observer may be presented with too many cues at one time, or the client may be attending to irrelevant cues. These limitations may be more than compensated for by the highly motivating and arousing effect of using a live social model. Symbolic models, by contrast, do 
offer the counsellor a greater amount of control in terms of content, format and timing. A video-taped social model can be developed and refined in advance of its actual use in a counselling situation (Krumboltz \& Thoresen, 1969:146, 166167).

\subsection{Models the learner identifies with}

Models suggest a style of action. The effect is not so much to teach a specific action as to suggest a range of behavioural patterns that will be tolerated (Cronbach, 1977:755; Craig et al., 1975:172). Many people influencing behavioural patterns are models at that instant only, never to be encountered again. Other individuals - real or fictional - are repeatedly used as guides. Such persons are identifying figures. The child's first identification is normally with his parents. They increase his happiness and take care of things that go wrong. The child's gratification broadens into identification which is stronger in a caring home. By the age of five, the child frequently picks playmates and older members of the family as models. Other adults become identifying figures. Pupils come to pursue the teacher's example, some so strongly that in the upper grades they are estranged from their peers. Others do not identify with the teacher (Cronbach, 1977:755; Craig et al, 1975:172; Childs, 1993:108-109). The Christian believer has the firm conviction that God never changes and that His example will not change in all eternity.

When a child identifies with somebody, he behaves as if he were that person. The emotional tie is so strong that he imagines himself to be the other person. This process is partially or even mostly unconscious, and the child gains status from such an identification. It is important that the child identifies with the likesexed parent so that he or she can develop attitudes, values, traits and behavioural patterns that are appropriate in society. If a child copies another person's behaviour, the term imitation is used. Imitation implies more superficial, specific and intentional behaviour than identification. The distinction between identification and imitation is unimportant, since both are regarded as social learning, and the key to social learning is modelling (Reilly \& Lewis, 1983:572).

Parents are the primary human models for the transmission of attitudes in the young child. During the early years, the teacher, as well as the parent, can serve as a human model for the child's learning of desirable attitudes such as consideration for others, completion of tasks, and fairness. No child imitates every action he sees. Sometimes he ignores the model his parents set and he adopts contrasting patterns from someone else (Gagné, 1985:234-235; Cronbach, 1977: 754-755). 


\subsubsection{Models consistent with the self-concept}

As the child develops into an adult, his identifying figures represent successive differentiations of his ideal. By the time he is of school going age, some adults seem more "his type" than others. A person seeks a model consistent with his needs and self-concept and copies his provisional attempts from this model (Cronbach, 1977:757).

By trusting in God and utilizing the advice of people (role models) around him through whom God works, man acquires self-knowledge and is enabled to choose correctly. Prior achievements, hobbies, part-time jobs and extraordinary experiences all contribute to one's self-concept and knowledge of oneself (Marais, 1983:195). God expects everyone to use his/her talents optimally to His glory. He delights in those who have good self-knowledge, makes decisions and work productively in his field (Matth. 25:23).

Factors such as the model's perceived expertise or competence, status or prestige, firmness, personal warmth, age, sex, ethnic status and organizational affiliations play an important role. Pupils readily identify with a caring accepting teacher, with school celebrities and with older students (Craig et al., 1975:172).

Teachers most admired by pupils - the ones who most often function as models are those who show personal interest. Other favoured traits are patience and fairness (Cronbach, 1977:759).

A child matches the behaviour of others with behavioural patterns already in the repertoire. It seems as if the behaviour of the model encourages parallel behaviour in the observer. The distinctive styles of the teacher as a model of social behaviour, his or her aggressiveness, friendliness, aloofness, cooperativeness, calmness, etc. will act as the initiators of novel behaviour changes in the child or will modify or trigger existing patterns. The teacher is an influential figure in the social behaviour modifications of children.

Pupils should be exposed to alternative models (Cronbach, 1977:765). Multiple role models have also been indicated as having a more persistent effect on gender-stereotyped attitudes than single models (Savenye, 1990:10).

According to the social learning theory of career decision-making, career role models can be important in influencing the career aspirations and interests of a decision-maker (Krumboltz \& Thoresen, 1969:163-165). Individuals who have observed a model perceived to be a high performer in a specific career or occupational field are more likely to express a preference for entering that career or field than individuals who have observed a model they perceive to be a low performer (Scherer et al., 1991:555). 


\subsubsection{Readiness to use models}

Some pupils are more influenced by models than others. Those who have experienced difficulty in social relations are not so readily influenced. Overdependence upon parents prevents attitude change; emotionally secure pupils are more free to change. A person with realistic aspirations meeting his own standards in an environment can identify more easily with a model. A person considering himself a failure cannot easily identify with teachers or successful peers (Cronbach, 1977:758).

\subsubsection{Characteristics of the observer}

Characteristics of the observer influencing imitative behaviour include such factors as the pupil's sex, race, socio-economic level and personality characteristics (dependency needs, achievement motivation, hostility level, cooperativeness, etc.). Boys often imitate aggressive behaviour more readily than girls: dependent pupils and those with a co-operative inclination (as opposed to a competitive orientation) are more apt to imitate models (Craig et al., 1975; Belkin \& Gray, 1977:46; Gagné, 1985:233).

\subsubsection{Expected consequences}

The consequences that pupils expect if they model their behaviour on that of another person is probably more important than the characteristics of either the model or the observer (Bandura, 1986:20-22). If the influence of a model is reinforced as a result of his behaviour, the pupil's tendency to imitate that behavioural pattern is increased; if the influence of the model is diminished the pupil will tend not to imitate him. A pupil is more likely to imitate the behaviour of models if he has been rewarded for doing so in the past. Pupils learn to imitate a model's behaviour when the conditions and consequences of doing so are gratifying (Craig et al., 1975:172; Belkin \& Gray, 1977:456; Gagné, 1985:233).

The more similar the model is to the observer, the more likely the observer is to conclude that he or she can obtain the same results by imitating the behaviour. However, if the consequences of the model's behaviour are uncertain or unknown, high-status models will exert the greatest influence (Tuckman, 1991:294).

\subsection{Teaching materials as a source of models}

Human modelling may occur in many learning situations. The model may be presented to the learner in pictures, movies or TV scenes and need not appear in person. Modelling can also take place in older children and adults when the model is merely described, as in a biography, a history text, or a novel (Gagné, 
1985:234; Gage \& Berliner, 1988:269-271; Tuckman, 1991:294). The Christian takes the Bible as the criterion for measuring or evaluating all role models.

According to Cronbach (1977:759-762) a lesson in a classroom situation can be positivily utilized by identifying role models whenever it describes people. In a certain sense books occasionally communicate aspects of the value system and attitudes of writers, intentionally or otherwise. Sometimes textbooks communicate prejudices, e.g. regarding sex or race stereotypes. The Christian role model should evaluate his value system and attitude by applying Biblical guidelines to implied prejudices.

Research has indicated that the presentation of career role models can influence attitudes towards careers. The medium through which role models are presented may also affect the impact. Printed material have frequently been used to present career role models. However, audio-visual media also seem to be effective for representing career role models. Media can enhance identification with the career role model by contributing evaluative information regarding the credibility and attractiveness of the model. Savenye (1990:6-10) recommends a well-planned programme over an extended period that would provide an opportunity for pupils to interact with a variety of role models and career-related activities.

\subsection{Conditions for learning attitudes through human role models}

According to Gagne (1985:47-48) there are certain conditions that have to be met in order to adopt attitudes through human role models. These conditions begin with the communication of key concepts and information as prerequisites. Information alone is not sufficient to change attitudes. Gagne contends that the critical conditions of attitude that change through modelling include the establishment of the model's appeal and credibility, as well as the opportunity to observe the model demonstrating, and being reinforced for, the desired course of action (Savenye, 1990:6)

Hacket et al. (1989:164) confirmed that role model influences are significantly related to career salience, level of education aspirations and nontraditionally of occupational choices. Performance self-esteem in addition to role model influences significantly predicted career salience, educational aspirations, and the nontraditionality of career choices, while gender-role variables are largely nonpredictive. Research by Hacket et al. (1989:170) showed that the following role models exerted a significant influence: parental influences were strongest, followed by other adults' influences, teacher influences and friends' influences.

Women having higher educational aspirations and stronger career salience tend to report strong female teacher role models and supportive adult males in their lives, 
but also have to handle negative reactions of male and female peers (Hacket et al., 1989:174). According to Watson and Allan (1989:700) men exhibit greater work-role salience. Watson and Allan (1989:701) found that the work-role salience of students enrolled for career-directed careers was significantly higher than that of students enrolled for general degrees.

The effectiveness of career role modelling in career education as an attempt to address the existing void in career information dissemination in South Africa was put to the test during the 1995 Potchefstroom Career 2000 Convention. A representative of $n=800$ Standard 9 and 10 pupils, all (36) attending guidance teachers and (36) career role models participated in the research project. Three different self-developed questionnaires, a separate one for each group, were completed, and the SAS computer programme was used to determine frequencies and percentages. The majority of respondents, $91,5 \%$ of the pupils, all the guidance teachers and $97,2 \%$ of the career role models regarded career role models as effective sources of career information dissemination. It was determined that a career role modelling programme can make a significant contribution to establishing an effective career information system in an diverse South African society (Landsberg, 1996:198).

\section{Implications for career education}

By introducing a career role modelling programme as method of career information dissemination, a significant contribution can be made to establish an effective career information system in a diverse South African society.

A model for the structuring of a South African career role modelling programme is the career cluster model which is based on the Chicago Careers of Youth programme and is presented over a period of time. According to the Central Economic Advisory Service (1996) the South African economy can be devided into ten clusters (see Figure 1).

The basic idea of the programme is to give career role models the opportunity to inform standard 4 and 5 pupils with details of the role models' present careers and also to give details of careers in related fields of expertise and areas of remuneration. The goal is that over a period of two years a career role model from each of the ten clusters will have spoken to every Standard 4 (Grade 6) and 5 (Grade 7) pupil. At the end of Standard 5 (Grade 7), each pupil will be able to select the cluster of greatest interest. During the career exploration phase in Standard 6 (Grade 8) and 7 (Grade 9) each pupil will be enabled to attend a careers day - thus in depth exploring the cluster of choice. 
Figure 1

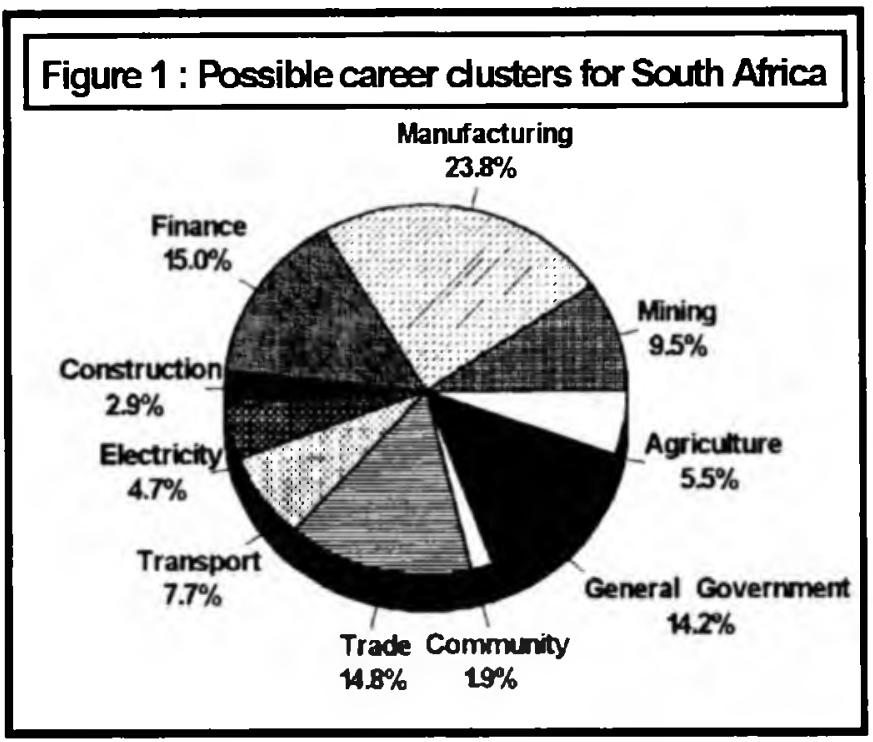

With five career role models a year, most schools can schedule one career role model about every second month. At these careers days a range of career role models from each cluster will discuss their careers.

According to Grant and Jackson (1995:5-8) role models can enhance career development in three areas, viz. self-assessment related to the occupational milieu, improving the abilities to use problem-solving strategies, and sharing information regarding the nature of their occupation and work environment.

Self-assessment includes grasping an understanding of our interests, abilities, aptitudes, values and personality traits and then coupling the identified characteristics to realistic and attractive job options. Career role models should be invited to address pupils and describe how their interests, abilities and aptitudes have influenced their career decisions. By sharing experiences, career role models provide the opportunity for pupils to see the relevance of personal strengths and weaknesses to career choice (Grant \& Jackson, 1995:5-6)

Career role models are in an ideal position to convey the message that one's interests and priorities may change after one's school career. Changing circumstances, such as marriage and the birth of children can lead to changes in our 
priorities. Role models can emphasize how their personalities and their values influence their job expectations. Sharing these kinds of experiences can, for example, assist pupils in understanding how self-assessment is related to career choice. In subtle ways, an orientation toward planning for the future can be addressed by helping pupils to anticipate future conditions (Grant \& Jackson, 1995:5-6).

Job descriptions can be enhanced by relating them to the current educational experience of pupils. When role models share information about the training paths that they have followed and point out how they have successfully applied knowledge which they previously had acquired at school level (and thus at the current developmental stage of the pupil) classroom experience can be related to pupils' future fields of work. Thus, the relevance of the curriculum to the occupational milieu and transferable skills are highlighted. Career role models may indicate how they overcame barriers; or how some barriers, experiences, or circumstances led to changes in their career objectives and training paths. Many career role models occupy careers not traditionally associated with their gender and have therefore resolved conflicts with traditional expectations.

Career role models can use a variety of ways presenting information ranging from factual information to "how-to" strategies while sharing job description information. Other topics which can be addressed by career role models could include, for example, the impact of career choice on lifestyle, how to handle jobrelated stress and how to manage the demands of a family with work related responsibilities. Thus, a number of the components of career exploration, in preparation for decision-making and implementation, can be presented by employed persons serving as career role models for pupils, thereby broadening pupils' knowledge bases. Just as there is a limitless number of jobs which can be described by career role models, there are a number of aspects of self-assessment, the nature of the occupational milieu and influences on the decision-making process which can be shared, illustrating how-to and problem-solving strategies (Grant \& Jackson, 1995:7-8). Implementing volunteer career role models reflects today's new spirit of volunteerism (George \& Bushnell, 1993:6).

\section{Conclusion}

Japan, the global economic power, is steeped in future-consciousness (Toffler, 1992:444). Since South Africa is also becoming a global competitor and finding itself in world-class company where winners are driven by a quest for excellence, a well-developed vision and future goals need to be spelled out, especially in education. The South African youth needs the vision of a "winning nation". Ordinary people need to be turned into champions, bringing out the best in them, liberating their spirit and making them leaders themselves (Sunter, 1992:183). 
To achieve this in an exhilarating period in South Africa's history is to a large extent a challenge to all those involved in any level of education in this country. Many inspiring and motivating role models and career role models are available to contribute to the ideal of a winning rainbow nation. The efforts of the role model who ascribes his/her successes to personal strenght are doomed to failure, as was the case with the potter: "Now and then a vessel he was making out of the clay would be spoilt in his hands ..." (Jer. 18:3). Jesus knows man and therefore invites every role model to allow him, Jesus, to form his life: "Can I not deal with you, Israel, says the Lord, as the potter deals with his clay?" (Jer. 18:6).

\section{References}

BANDURA, A. 1986. Social foundations of thought and action: a social cognitive theory. Englewood Cliffs, N.J. : Prentice-Hall.

BELKIN, G.S. \& GRAY, J.C. 1977 Educational psychology: an introduction. Dubuque, Iowa : Brown.

BERGER, R L., FEDERICO, R.C. \& McBREEN, J.T. 1991. Human behavior: a perspective for the helping professions 3rd ed. New York : Longman

BORGOTTA, E F \& BORGOTTA, M L 1992. Encyclopedia of sociology. 3:1678-1681

BOUDREAU, F.A., SENOTT, R.S \& WILSON, M. eds. 1986. Sex roles and social patterns. New York : Praeger.

BRONKHORST, M. \& VAN ROOYEN, E. 1995. Interview with the author at the Department of Labour. Klerksdorp

CHILDS, D. 1993. Psychology and the teacher. 5th ed London : Casse.

CLARK, S.M. \& CORCORAN, M 1986. Perspectives on the professional socialization of women faculty: a case of accumulative disadvantage? Journal of Higher Education, 57(1):20-41, Jan./Feb

CRAIG, R., MEHRENS, W. \& CLARIZIO, H. 1975. Contemporary educational psychology: concepts, issues, applications. New York : Wiley.

CRONBACH, L.J 1977. Educational psychology 3rd ed New York : Harcourt Brace Jovanovich.

DUVENAGE, B. s.a. Beroepsarbeid in die lig van die Gereformeerde etiek Potgietersrus : Die Morester

GAGE, N.L \& BERLINER, D C. 1988 Educational psychology Boston : Mifflin

GAGNE, R.M 1985 The conditions of learning and theory of instruction. 4th ed. New York : Holt, Rinehart \& Winston

GEORGE, P S. \& BUSHNELL, D. 1993. What works and why? The key to successful advisement activities. Schools in the Middle, 3(1):3-9, Sept

GNAEDINGER, J P. 1996. Letter to author, 17 January. Chicago. Ill. Original copy in author's possession. Potchefstroom.

GOVE, P.B. ed. 1961. Webster's third new international dictionary. Springfield, Mass. Mirriam.

GRANT, D.F. \& JACKSON, M.H. 1995 Career day programs for today's youth. Georgia Southern University. USA Department of Education (Photocopy - Educational Resources Information Centre - ERIC.)

HACKET, G., ESPOSITO, D \& O'HALLORAN, M S. 1989. The relationship of role model influences to the career salience and educational and career plans of college women Journal of Vocational Behavior, 35(2): 165-180, Oct. 
HERR, E.L \& CRAMER, S.H. 1996. Career guidance and counselling through the life span. New York . Harper Collins College Publishers.

HOMAN, KB 1986 Vocation as the quest for authentic existence. The Career Development Quarterly, 35:14-23.

ISAACSON, L.E. 1986. Career information in counselling and career development 4th ed Boston : Allyn \& Bacon

JARY, D \& JARY, J. 1991 The Harper Collins dictionary of sociology. New York : Harper Perennial.

JUNG, J 1986. How useful is the concept of role model?: A critical behaviour analysis. Journal of Social Behaviour and Personality, 1(4):525-536, Oct.

KOKOT, S. 1993 . Vital preparation for the world of work. Supplement to the Potchefstrooom Herald, Carletonville Herald, North Free State Gazette 1, Aug. 6.

KRUMBOLTZ, J.S. \& THORESEN, C.E. eds 1969. Behavioral counselling: cases and techniques Stanford, Calif. : Holt, Rinehart and Winston

LACY-SMITH, M J. 1992. A qualitative evaluation of a career information exhibition. Johannesburg : RAU. (Dissertation-M.A.)

LANDSBERG, S. 1996. Career role modelling as method in career education. Potchefstroom : PU vir CHO. (Thesis - Ph.D.)

LIEBERMAN, S. 1966. The effects of changes in roles on the attitudes of role occupants. Human Relations, 9:385-402

MARAIS, J L. 1983. Die Christen in sy beroepskeuse en -lewe (In Verankerde voortgang Wetenskaplike bydraes van die PU vir CHO Reeks J: Potchefstroomse studies in Christelike wetenskap. Reeks J I: Wetenskap in U Lig. Nommer 5, band 3. Sentrale Publikasie. PU vir CHO : Potchefstroom. p 188-201.)

OXFORD ENGLISH DICTIONARY. 1978. "Model". Vol vi. Cape Town : Oxford University Press.

REILLY, R.R \& LEWIS, E.L 1983. Educational psychology: applications for classroom learning and instruction New York : Macmillan

SAVENYE, W.C. 1990 Role models and students attitudes toward non-traditional careers Educational, Technology, Research and Development, 38(3):5-13.

SCHERER, R E , BRODZINSKI, J.D \& WIEKE, F A. 1991. Assessing perception of career role-model performance: the self-employed parent Perceptual and Motor Skills, 72(2):555-560, April.

SUNTER, C. 1992. The new century: quest for the high road. Cape Town : Human \& Rousseau.

TOFFLER, A. 1992. Powershif: knowledge, wealth and violence at the edge of the $21 \mathrm{st}$ century. London : Bantam Books.

TUCKMAN, B W. 1991. Educational psychology: from theory to application. New York : Harcourt Brace Jovanovich.

WATSON, M B \& ALLAN, M.M 1989 Work-role salience: comparison of students in career-directed and general degree courses Psychological Reports, 64:699-7704 